\title{
INVESTIGATION OF PRACTICAL LIFE LINE RCC MULTISTORIED BUILDING STRUCTURE \& ITS CONCRETE GRADE--OF HYDRABAD KARNATAKA
}

\author{
Tanveer Asif Zerdi ${ }^{1}$, Ghyan Sham Prasad Singh Khare ${ }^{2}$ \\ ${ }^{1}$ Research Scholar, Civil Engineering, JJT University, Rajasthan, India \\ ${ }^{2}$ Principal, Civil Engineering, Govt Engg College, jagdalpur, Chhattisgarh, India
}

\begin{abstract}
As a part work of searching the easy and simple way of structural analysis and design to the practical life line structure (Commonly permitted and constructed Reinforced cement concrete (RCC) Multistoried building structure in Hyderabad Karnataka area of Karnataka state), this work is carried out which has a resulted in a breakthrough as it gives easy guide for analysis and design to many of technocrats who are unconfident in practical structural design. Hence, in this work mot commonly permitted and constructed RCC multistoried building structure of Hyderabad Karnataka is investigated and details of grade of concrete used in construction of its components. The most commonly permitted by civic authorities and hence constructed, RCC multistoried building structures of the area is termed by author over here as practical life line structure, as this structure comes frequently in their life line for structural design and construction. The data gathered has revealed some astonishing results that the practical life line structure arrived was not a huge, technically complicated multistoried building structure but it was simple ground plus three storied RCC commercial building having regular layout, and having simpler sections and components were cast mostly by using M20 to M25 Grade of concrete.
\end{abstract}

Keywords: Concrete, RCC, Structural analysis, structural design, Practical life line structure.

$* * *$

\section{INTRODUCTION}

This research paper is the part work of finding out of feasible analysis and design way which can be adopted to do structural analysis and structural design of practical life line structure. Author means the practical life line structure as a building structure which is frequently permitted and commonly constructed RCC multistoried building structure in Hyderabad Karnataka area ( Gulbarga, Bidar, Raichur, Yadgir Districts are considered over here) of Karnataka state. The first most frequently/commonly constructed structure is known by the author as life line structure as this structure frequently comes in their life line for structural design., The Hyderabad Karnataka area of Karnataka state is the most backward area of Karnataka state where government of India is implementing the article 371 of the constitution to give special facilities to this area. Educationally this area is very backward, absolutely no training facilities to training the latest available structural design software's is available over here. The topic feasible analysis and design way for practical life line structure is the outcome of persistent demand from many of the students, practicing engineers, some building designers, fresh engineering graduates and post graduates, specifically many practicing government engineers who are unable to design with confidence the building structure which they encounter normally in day to day life in spite of getting sufficient academic qualification, and frequently they are found visiting structural consultants for the same in this area, that encouraged the author to do the research work under consideration. It is noted that it is a burning problem for engineering students, practicing engineers, even for some building designers, fresh civil engineering graduates and civil engineering related post graduates, specifically many of the government engineers, to arrive at a simplified and easy way of structural analysis and equally simplified and easy way of structural design method which can be searched and hence can be adopted (With confidence, without confusion and without tiresome and time consuming calculations and without using large memories of the computers and advanced structural analysis software's which are available in the market, without much affecting the limitations of technicalities like economy elegance, durability and safety and serviceability conditions by adopting assumptions/idealizations) to the, frequently constructed RCC multistoried building structure amongst the RCC multistoried building structures permitted/constructed in Hyderabad Karnataka area of Karnataka state. As it is presumed that, amongst buildings relatively tall structure building is technically difficult to analyze and design, and hence to give a solution of relatively technically difficult building structures to needy technocrats amongst the building structures they encounter in day to day life the frequently permitted or constructed tall building structure is selected as an ideal problem, which is called as life line structure by the author. The easiest and simplest way of structural analysis 
and structural design of these structures gives a ready reference guide for above cited technocrats and increase confidence in them to do analysis and design. This analysis/design is done through extensive survey of different books of civil and structural engineering domain, and journals, different Indian standard codes of practice etc. Calculation of exact bending moments in single span slabs or beams do not pose any problem They can be obtained directly using coefficient for standard loading cases available in various Indian standard design aids. Indian standard code of practice IS 4562000 prescribe co-efficient for continuous beams/slabs with approximately equal spans (Variation between long and short span not exceeding $15 \%$ of long span) and carrying uniformly distributed load. The co-efficient for equal spans continuous slab/beam for other standard loading like central point load or equal point loads at $1 / 4^{\text {th }}$ or $1 / 3^{\text {rd }}$ span points are also available in various design aids [1]. In the third degree level of approximation, instead of taking all beam segments and all columns in the adjacent two stories this frame is further sub divided into separate bay frames each one consisting the beam of interest together with connected columns and beams in the adjacent spans only, fixed at their far ends. Such a frame is called substitute bay frame since beams beyond the adjacent spans are not considered but assumed to be fixed, their stiffness get over estimated. Therefore, their stuffiness is reduced to half to allow for the flexibility resulting from continuity [2]. An efficient analysis procedure to evaluate the seismic performance of reinforced concrete buildings in Bangkok is presented. In this procedure, the performance is determined by comparing the "pushover" capacity curve of the building with Bangkok's seismic demand spectra. The demand spectra are derived from the constant-ductility yield strength demand spectra of predicted earthquake ground motions in Bangkok for various return periods. A 9-story frame building in Bangkok is chosen as a case study to demonstrate the capability of the procedure. A research plan to apply this procedure to check the seismic performance of many existing buildings in Bangkok is also presented [3]. In $2^{\text {nd }}$ international conference on urban disaster reduction In this study, a typical mid-rise residential building and a typical lowrise commercial building in Bangkok are selected and examined in details. However, only the first case is presented in this report. The selected building is a 4 -story apartment [4]. The provision of shear walls symmetrically in the outermost moment resisting frames of the building and preferably interconnected in mutually perpendicular directions forming a core will lead to better seismic performance [5]. Designers often conceived independent structural systems to support gravity loads and for resisting earthquake lateral loads. The lateral load resisting system was designed for high levels of ductility. For gravity loads, the benefit of ductility cannot be taken, and, therefore, the gravity load resisting system was designed to be non-ductile. Consequently, the lateral load resisting system tended to be flexible with a high level of ductility, whereas members of the gravity load resisting system tended to be relatively stiff, low in strength and brittle for lateral loads [6].

\subsection{Objective}

The two objectives are as follows

1) Searching for practical life line structure (most commonly constructed RCC multistoried building structure in (1. Gulbarga 2. Bidar 3. Raichur 4. Yadgir.) Districts of of Hyderabad Karnataka area.

2) Study the Grade of concrete used in construction of different components of the Practical life line structure.

\section{METHODS AND METHODOLOGY}

For reaching to the objectives as mentioned, the following methodology is adopted.

By extensive investigation from the responsible technocrats as decided, are contacted from (1. Gulbarga 2. Bidar 3. Raichur 4. Yadgir.) Districts of Hyderabad Karnataka, and data is collected as follows

\subsection{Data Collection}

100 No's of Extensive information of RCC multistoried building structures having no of stories equal to or more than Ground plus three stories or more, which are permitted by civic authorities and hence got constructed during previous 15 years in Hyderabad Karnataka area of Karnataka state is gathered. For this purpose 100 No's of Different technocrats like Engineers of civic authorities, Civil engineering contractors, Structural consultants, are contacted to collect information, Also personnel observation is done, from different cities of Hyderabad Karnataka area namely 1) Gulbarga 2) Bidar 3) Raichur 4) Yadgir. Only respondents from cities are selected as high rise constructions seldom takes place in areas beyond city limits. The technocrats selected as above are met personally and with proper discussion with them on technicalities of the structure and also by personnel observation the data is gathered, The Data collected and is properly tabulated in the tables for analysis to reach to targeted conclusion

\section{RESULTS AND DISCUSSION}

The data collected for searching frequently permitted and constructed tall building structure having minimum Ground plus three stories, of Hyderabad Karnataka area amongst the permitted and constructed tall building structures from different technocrats/relevant responsibilities is gathered after detailed discussion with them and is tabulated as follows.

Table-1 show the number to ground plus three storied or more structures got constructed in different districts in past 15 years. 
In all the districts G+3 storied structures are far more compared to the structures which are more than $\mathrm{G}+3$ stories. It shows that the structure under investigation is Ground plus three storied one.

Table-1: Quantum of G+3 storied or more, Building structures in different Selected Districts of Hyderabad Karnataka

\begin{tabular}{|c|l|c|c|c|}
\hline $\begin{array}{c}\text { Sl } \\
\text { No }\end{array}$ & $\begin{array}{c}\text { District } \\
\text { Name }\end{array}$ & $\begin{array}{c}\text { G+3 } \\
\text { Storied } \\
\text { Buildings } \\
\text { (a) }\end{array}$ & $\begin{array}{c}>\text { G+3Storied } \\
\text { Buildings (b) }\end{array}$ & Remarks \\
\hline 1 & Gulbarga & 59 & 26 & $\mathrm{a}>\mathrm{b}$ \\
\hline 2 & Bidar & 48 & 23 & $\mathrm{a}>\mathrm{b}$ \\
\hline 3 & Raichur & 45 & 21 & $\mathrm{a}>\mathrm{b}$ \\
\hline 4 & Yadgir & 20 & 07 & $\mathrm{a}>\mathrm{b}$ \\
\hline
\end{tabular}

Similarly Table 2 shows the split up of the different nature of buildings like 1. Purely commercial buildings 2 Purely Residential buildings 3 Residential cum commercial buildings, got constructed in total number of Ground plus three storied buildings, got constructed in different districts. The largest number is of $\mathrm{G}+3$ storied commercial buildings, second largest is $\mathrm{G}+3$ storied residential buildings third large is $\mathrm{G}+3$ storied residential cum commercial buildings.

Table- 2: Quantum of G+3 storied or more, Residential /Commercial/ Residential cum Commercial Building structures in different selected districts.

\begin{tabular}{|c|l|c|c|c|c|}
\hline S1 No & District Name & $\begin{array}{c}\text { G+3Storied } \\
\text { Commercial buildings } \\
\text { (a) }\end{array}$ & $\begin{array}{c}\text { G+3 Storied } \\
\text { Residentil } \\
\text { Buildings (b) }\end{array}$ & $\begin{array}{c}\text { G+3Storied } \\
\text { Residential cum } \\
\text { Commercial buildings } \\
\text { (c) }\end{array}$ & Remarks \\
\hline 1 & Gulbarga & 37 & 18 & 5 & $\mathrm{a}>\mathrm{b}>\mathrm{c}$ \\
\hline 2 & Bidar & 30 & 14 & 4 & $\mathrm{a}>\mathrm{b}>\mathrm{c}$ \\
\hline 3 & Raichur & 27 & 15 & 4 & $\mathrm{a}>\mathrm{b}>\mathrm{c}$ \\
\hline 4 & Yadgir & 12 & 6 & 2 & $\mathrm{a}>\mathrm{b}>\mathrm{c}$ \\
\hline
\end{tabular}

Likewise for computing the different Grades of concrete used in the construction of $\mathrm{G}+3$ storied commercial buildings the Table 3 is drawn which shows number of buildings got constructed by using (M20-M25) Grade of concrete used in their different components in different districts. Majority of building components got constructed by using (M20-M25) grade of concrete.

Table -3: Number of G+3 storied commercial buildings components build by (M20-M25) Grade of concrete

\begin{tabular}{|c|c|c|c|c|c|c|c|c|}
\hline \multirow[t]{2}{*}{$\begin{array}{c}\text { Sl } \\
\text { No }\end{array}$} & \multirow[t]{2}{*}{ District } & \multicolumn{3}{|c|}{$\begin{array}{c}\text { No of G+3 Storied } \\
\text { commercial buildings/their } \\
\text { components constructed with } \\
\text { particular Grade of concrete }\end{array}$} & \multicolumn{4}{|c|}{$\begin{array}{l}\text { Grade of concrete used for respective } \\
\text { components of the building structure } \\
\text { constructed } \\
\text { M20-M25 range i:e Group-I }\end{array}$} \\
\hline & & Total & $\begin{array}{l}\text { M20-M25 } \\
\text { Grade } \\
\text { concrete } \\
\text { Group-I }\end{array}$ & $\begin{array}{c}>\mathrm{M} 25 \\
\text { Grade } \\
\text { concrete } \\
\text { Group-II }\end{array}$ & Slab & Beams & Columns & Footings \\
\hline 1 & Gulbarga & 37 & 32 & 5 & M20 & M20 & M25 & M20 \\
\hline 2 & Bidar & 30 & 27 & 3 & M20 & M20 & M25 & M20 \\
\hline 3 & Raichur & 27 & 24 & 03 & M20 & M20 & M25 & M20 \\
\hline 4 & Yadgir & 12 & 11 & 01 & M20 & M20 & M25 & M20 \\
\hline
\end{tabular}


Likewise for computing the different Grades of concrete used in the construction of $\mathrm{G}+3$ storied commercial buildings the Table 4 is drawn which shows number of buildings got constructed by using (>M25) Grade of concrete used in their different components in different districts. Majority of building structures components were built by using M20-M25 range i:e Group-I o concrete Only in Gulbarga districts mere 5 number of building that also only colums were built by using M30 Grade of concrete.

Table -4: Quantification of (>M25) Grade of concrete used in different components of G+3 Storied commercial buildings

\begin{tabular}{|c|c|c|c|c|c|c|c|c|}
\hline \multirow[t]{2}{*}{$\begin{array}{c}\text { Sl } \\
\text { No }\end{array}$} & \multirow[t]{2}{*}{ District } & \multicolumn{3}{|c|}{$\begin{array}{l}\text { No of G+3 Storied commercial } \\
\text { buildings/their components } \\
\text { constructed with particular Grade of } \\
\text { concrete }\end{array}$} & \multicolumn{4}{|c|}{$\begin{array}{l}\text { Grade of concrete used for respective } \\
\text { components of the building structure } \\
\text { constructed } \\
\text { >M25 Grade concrete i:e Group-II }\end{array}$} \\
\hline & & Total & $\begin{array}{l}\text { M20-M25 } \\
\text { Grade } \\
\text { concrete } \\
\text { Group-I }\end{array}$ & $\begin{array}{l}>\mathrm{M} 25 \\
\text { Grade } \\
\text { concrete } \\
\text { Group-II }\end{array}$ & Slab & Beams & Columns & Footings \\
\hline 1 & Gulbarga & 37 & 32 & 5 & M20 & M20 & M30 & M20 \\
\hline 2 & Bidar & 30 & 27 & 3 & M20 & M20 & M25 & M20 \\
\hline 3 & Raichur & 27 & 24 & 03 & M20 & M20 & M25 & M20 \\
\hline 4 & Yadgir & 12 & 11 & 01 & M20 & M20 & M25 & M20 \\
\hline
\end{tabular}

\section{CONCLUSIONS}

From the above results and discussions the following conclusions can be drawn

1) From the above discussion it can be concluded that the most commonly or frequently constructed buildings of 1) Gulbarga 2) Bidar 3) Raichur 4) Yadgir. Districts of Hyderabad Karnataka area which is termed by author as practical life line structure, is not a complicated huge multistoried building, but it is a simple Ground plus three storied commercial building.

2) The Grade of concrete used in the construction of these practical life line structures components is by using M20 to M25 Grade of concrete.

\section{REFERENCES}

[1] Indian standard code of practice IS 456-2000

[2] Mosley. W.H. Bungey. J. H. Hulse R (1999) "Reinforced concrete Design" Macmillan press and K. L. Rao "Reinforced concrete" charotar publication

[3] Björk Hauksdóttir (February 2007) "Analysis of a Reinforced Concrete Shear Wall"

[4] Chung-Yue Wang and Shaing-Yung Ho (Nov 2007) "Pushover Analysis for Structure Containing RC Walls", In $2^{\text {nd }}$ international conference on urban disaster reduction nov-2007.

[5] Sudipta Chattopadhyaya and Amlan K. Sengupta "Modelling of tall shear walls for pushover analysis of reinforced concrete buildings" by, In ACI- structural journal Title No 107-S08.

[6] Krawinkler H., and senevirantna G.D.PK. (1997) "pros and cons of a pushover analysis of seismic performance 